\title{
Noncompaction of the Ventricular Myocardium and Hydrops Fetalis in Cobalamin C Disease
}

\author{
Pranoot Tanpaiboon • Jennifer L. Sloan • \\ Patrick F. Callahan • Dorothea McAreavey • \\ P. Suzanne Hart • Uta Lichter-Konecki • Dina Zand • \\ Charles P. Venditti
}

Received: 17 October 2012 /Revised: 17 October 2012 /Accepted: 30 October 2012 /Published online: 29 December 2012

(C) SSIEM and Springer-Verlag Berlin Heidelberg 2012

\begin{abstract}
Cobalamin C disease ( $c b l \mathrm{C})$, a form of combined methylmalonic acidemia and hyperhomocysteinemia caused by mutations in the $M M A C H C$ gene, may be the most common inborn error of intracellular cobalamin metabolism. The clinical manifestations of $c b l C$ disease are diverse and range from intrauterine growth retardation to adult onset neurological disease. The occurrence of structural heart defects appears to be increased in $c b l C$ patients and may be related to the function of the MMACHC enzyme during cardiac embryogenesis, a concept supported by the observation that Mmachc is expressed in the bulbis cordis of the developing mouse
\end{abstract}

Communicated by: Olaf Bodamer

Competing interests: None declared

P. Tanpaiboon · U. Lichter-Konecki · D. Zand

Division of Genetics and Metabolism, Children's National Medical Center, Washington, DC 0010, USA

J.L. Sloan · C.P. Venditti $(\triangle)$

Organic Acid Research Section, Genetics and Molecular Biology

Branch, National Human Genome Research Institute, National

Institutes of Health, Building 49, Room 4A18, Bethesda,

MD 20892, USA

e-mail: venditti@mail.nih.gov

P.F. Callahan

Child Cardiology Associates, Fairfax, VA 22031, USA

D. McAreavey

Critical Care Medicine Department, National Institutes of Health (NIH), Bethesda, MD 20892, USA

P.S. Hart

Office of the Clinical Director, Medical Genetics Branch, National Human Genome Research Institute (NHGRI), National Institutes of Health (NIH), Bethesda, MD 20892, USA heart. Here we report an infant who presented with hydrops fetalis, ventricular dysfunction, and echocardiographic evidence of LVNC, a rare congenital cardiomyopathy. Metabolic evaluations, complementation studies, and mutation analysis confirmed the diagnosis of $c b l C$ disease. These findings highlight an intrauterine cardiac phenotype that can be displayed in $c b l \mathrm{C}$ disease in association with nonimmune hydrops.

\section{Introduction}

Cobalamin C disease ( $c b l \mathrm{C}$ ), a form of combined methylmalonic acidemia and hyperhomocysteinemia, may be the most common inborn error of intracellular cobalamin metabolism and is caused by mutations in MMACHC gene located on chromosome 1p34 (Lerner-Ellis et al. 2006). In the "early onset" form of $c b l \mathrm{C}$, infants present with failure to thrive, developmental delay, visual impairment, and hematologic problems (Carrillo-Carrasco et al. 2011; Rosenblatt et al. 1997). Malformations including congenital microcephaly and congenital heart diseases are frequently present (Andersson et al. 1999). While the phenotypic spectrum of $c b l C$ disease is broad and age of onset is variable, encompassing prenatal and adult presentations, a prenatal cardiac presentation of right ventricular dilated cardiomyopathy in the third trimester has been documented in one infant with $c b l C$ disease (De Bie et al. 2009). Here, we describe a patient with $c b l C$ disease who presented with the combination of hydrops fetalis and left ventricular noncompaction (LVNC), review the previous reports of cardiomyopathy in $c b l \mathrm{C}$ disease, and highlight the need to consider the diagnosis of $c b l C$ disease in the setting of nonimmune hydrops fetalis, especially when cardiac disease is present in the fetus. 


\section{Case Report}

Clinical investigations were conducted through NIH study 04-HG-0127 "Clinical and Basic Investigations of Methylmalonic Acidemia and Related Disorders" (clinicaltrials. gov identifier: NCT00078078) in compliance with the Helsinki Declaration. The patient was born to a healthy 35-year-old primigravida. A routine prenatal ultrasound at 12 weeks showed an increased nuchal translucency and subsequently chorionic villus sampling demonstrated a normal female karyotype, 46,XX. At 20 weeks, a prenatal ultrasound showed a thickened nuchal fold. Fetal echocardiography suggested possible tricuspid atresia and insufficiency with poor right ventricular function. Repeat evaluation at 24 weeks demonstrated questionable pulmonic stenosis and impaired biventricular function. Significant hydrops fetalis was also noted and the fetus was not expected to survive. At 30 weeks, a fetal echocardiogram revealed poor right ventricular function with preserved left ventricular systolic function. Deep trabeculations of both ventricles with a thickened septum were clearly visualized at the apex (Fig. 1a). Surprisingly, the hydrops nearly resolved by 35 weeks.

This infant was delivered at 38 weeks by scheduled Cesarean section. The birth weight was $2.72 \mathrm{~kg}$ (10th percentile), birth length was $49.3 \mathrm{~cm}$ (50th percentile), and head circumference was $34 \mathrm{~cm}$ (50th percentile). Clinical heart failure manifested shortly after birth and required inotropic support including dopamine, dobutamine, and digoxin. An echocardiogram on the first day of life demonstrated bilateral poor ventricular function, hypertrabeculation of the left ventricle, perfusion of trabecular recesses by Doppler color flow, and $>2: 1$ ratio of compacted to noncompacted myocardium, consistent with left ventricular noncompaction (LVNC). A screen for metabolic disorders was conducted and revealed methylmalonic aciduria (urine methylmalonic acid (MMA) 330 $\mu \mathrm{mol} / \mathrm{mmol}$ creatinine; normal $<5.1$ ), hyperhomocysteinemia (total homocysteine (tHcy) $180 \mu \mathrm{mol} / \mathrm{L}$; normal 5-13), and hypomethioninemia (methionine $6 \mu \mathrm{mol} / \mathrm{L}$; normal 8-51) consistent with a diagnosis of an intracellular vitamin B12 disorder. Hydroxycobalamin, betaine, carnitine, folate, and aspirin were administered and a reduced protein diet was prescribed. After treatment, the levels of urine MMA and plasma tHcy decreased significantly (urine MMA 165 $\mu \mathrm{mol} / \mathrm{mmol}$; creatinine and tHcy $59.2 \mu \mathrm{mol} / \mathrm{L})$, and plasma methionine increased to the normal range $(22 \mu \mathrm{mol} / \mathrm{L})$. The diagnosis of $c b l \mathrm{C}$ was established by cellular biochemical studies in the laboratory of Dr. David Rosenblatt (McGill University, Montreal, Canada). Her fibroblasts demonstrated diminished incorporation of propionate and methyl-THF, diminished synthesis of adenosyl- and methylcobalamin, and failed to complement cells of the $c b l \mathrm{C}$ class.

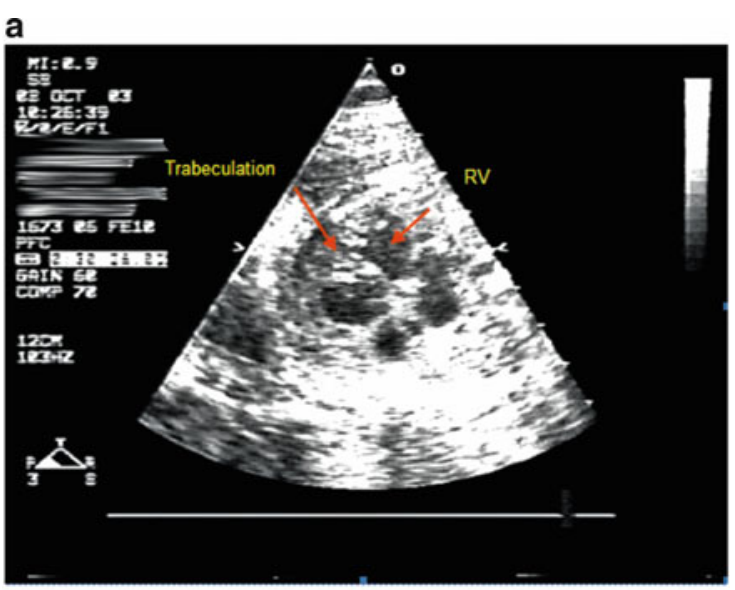

b

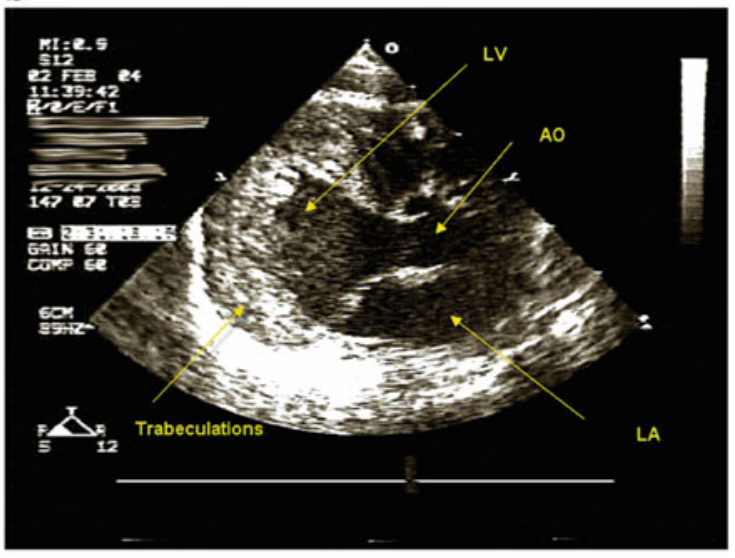

C

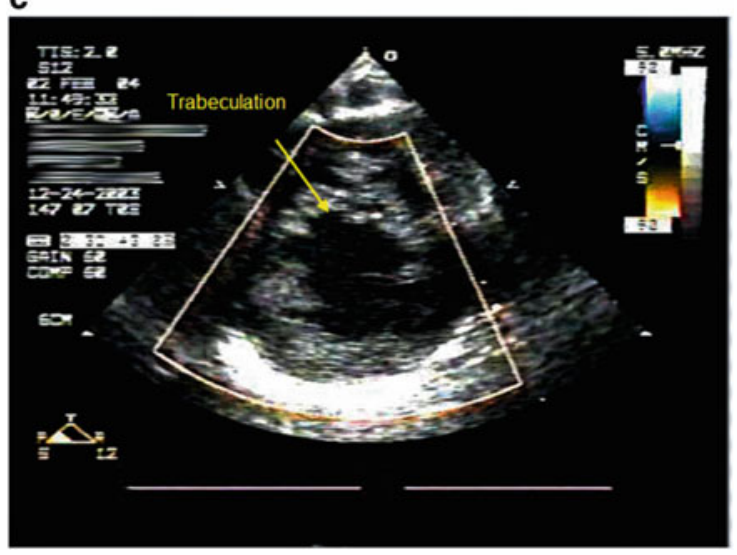

Fig. 1 Selected echocardiographic images. (a) Fetal echocardiography at 30 weeks (parasternal short axis view) showed hypertrabeculation (arrows) of both ventricles. (b) Echocardiography at 1 month (parasternal long axis view) revealed a globular apex. (c) Echocardiography at 1 month (parasternal short axis view) shows multiple deep trabeculations at the apex of the left ventricle

Sequence analysis of the $M M A C H C$ gene detected a homozygous mutation, c.271dupA. To rule out the possibility that uniparental disomy (UPD) at the $M M A C H C$ locus was present in the patient, 21 markers spaced along chromosome 1 that mapped $8.3 \mathrm{Mb}$ telomeric and 
$1.0 \mathrm{Mb}$ centromeric to the $M M A C H C$ gene were analyzed. The patient was heterozygous at 19 informative markers indicating there was no evidence of UPD or microdeletion around the MMACHC locus (data not presented). Other postnatal genetic investigations included a high-resolution karyotype and subtelomere FISH studies, both of which were normal.

At 1 month of age, an echocardiogram demonstrated poor left ventricular (LV) function, with estimated ejection fraction (LVEF; 43\%) and decreased LV fractional shortening (LVFS; 20\%). Noncompaction was noted at the apex of the LV (Fig.1b, c). At 8 months, LV function had improved (70\% EF and 40\% LVFS), but noncompaction was still evident at the apex of the LV. At 30 months of age, ventricular function had stabilized and the cardiac morphology, except for a mild globular appearance of the left ventricle, appeared normal. Digoxin therapy had been initiated in early life and was continued.

Other clinical findings consistent with $c b l \mathrm{C}$ deficiency, such as feeding difficulties, macular changes, and developmental delay were present. Both parents had normal echocardiograms.

\section{Discussion}

Cardiac manifestations of $c b l \mathrm{C}$ disease have been described and include several congenital abnormalities (Andersson et al. 1999; Martinelli et al. 2010; Profitlich et al. 2009), cardiomyopathy (Martinelli et al. 2010; Profitlich et al. 2009), and endocardial fibrosis (Baumgartner et al. 1979; Geraghty et al. 1992; McCully 1969). At least 15 patients with $c b l \mathrm{C}$ have been reported with cardiomyopathy (Table 1; Baumgartner et al. 1979; Brandstetter et al. 1990; Carmel et al. 1980; Chenel et al. 1993; De Bie et al. 2009; Longo et al. 2005; Geraghty et al. 1992; Ogier de Baulny et al. 1998; Profitlich et al. 2009). However, the specifics regarding the type and echocardiographic manifestations of the cardiac lesions have not been fully delineated. Only three out of fifteen previously reported patients were diagnosed with LVNC (Profitlich et al. 2009); one additional patient displayed prominent left ventricular apical trabeculation but did not meet the criteria of noncompaction cardiomyopathy (Profitlich et al. 2009). Although an association with the underlying disorder has been assumed, none of the previously reported patients were evaluated for familial and genetic causes of noncompaction and, except for this report, parental echocardiograms were not performed. Biochemical and molecular genetic data (Table 2) have not uniformly been documented, although in several instances, the patients have had mutations and a clinical course consistent with "early onset" disease (Rosenblatt et al. 1997). Cobalamin C disease has also been documented in a single patient who presented with dilated cardiomyopathy, diminished systolic function, hypocontractility of the left ventricle, and intrauterine growth retardation (De Bie et al. 2009). Left ventricular noncompaction (LVNC) was not described in this infant. It therefore remains to be determined whether LVNC is present in all $c b l C$ patients, if there is a correlation with $M M A C H C$ genotype(s), an association with the magnitude of metabolite elevations and/or the age of diagnosis or treatment.

Left ventricular noncompaction is a genetically heterogeneous condition that occurs because of failure of normal myocardial maturation during cardiac embryogenesis (Chin et al. 1990; Ichida 2009) and results in prominent trabeculations, particularly in the left ventricle (Chin et al. 1990; Ichida. 2009). LVNC can occur in patients with malformation syndromes, including velocardiofacial syndrome (Madan et al. 2010), Sotos syndrome (Martinez et al. 2011), as well as states of aneuploidy and mosaicism (Beken et al. 2011; McMahon et al. 2005; Sellars et al. 2011; Wang et al. 2007). Furthermore, LVNC has been reported in association with several distinct inborn errors of metabolism (IEM) including Barth syndrome (Bleyl et al. 1997); Pompe disease (Finsterer et al. 2006); Fabry disease (Stöllberger et al. 2003); cobalamin C disease (Profitlich et al. 2009); numerous mitochondrial disorders including Leber's hereditary optic neuropathy (LHON) (Finsterer et al. 2002); mitochondrial myopathy, encephalopathy, lactic acidosis, and stroke (MELAS) syndrome as well as less well-defined mitochondriopathies (Finsterer et al. 2006; Stöllberger et al. 1999). In at least one case, isolated LVNC has manifested as fetal hydrops (Richards et al. 2009).

There are several genes associated with isolated LVNC including G4.5 (TAZ), dystrobrevin (DTNA), LIM domainbinding protein 3 (Cypher/ZASP: LDB3), Lamin A/C (LMNA), SCN5A, and sarcomere proteins ( $\beta$-myosin heavy chain, $\alpha$-cardiac actin $(A C T C)$, cardiac troponin T [TNNT2], tropomyosin 1 [TPMI]) (Xing et al. 2006; Ichida 2009; Chang et al. 2011). These gene products have functions related to cytoskeletal and/or mitochondrial function (Tang et al. 2010). Another six loci located on chromosomes $1 \mathrm{p} 36$ (Thienpont et al. 2007), 1q43 (Kanemoto et al. 2006), 5q35 (Pauli et al. 1999), 8p23 (Blinder et al. 2011), and 11p15 (Sasse-Klaassen et al. 2004) also have been linked to the phenotype of nonsyndromic LVNC. While a number of genes and candidate loci have been reported with LVNC, only a minority of affecteds have been found to harbor causative mutations (Finsterer et al. 2004; Ichida 2009; Tang et al. 2010; Xing et al. 2006). Although we and others have not able to rule out other genetic causes of LVNC in manifesting patients, that fact that other $c b l C$ patients have been diagnosed with LVNC (Profitlich et al. 2009) and that the parents were unaffected in the case reported here provides some support for an association between $c b l C$ disease and LVNC. 
Table 1 Clinical features of congestive heart failure and cardiomyopathy in $c b l C$ disease

\begin{tabular}{|c|c|c|c|c|}
\hline Reference & $\begin{array}{l}\text { Number of } \\
\text { patients }\end{array}$ & $\begin{array}{l}\text { Cardiac } \\
\text { manifestations }\end{array}$ & Echocardiography & Pathology \\
\hline $\begin{array}{l}\text { Baumgartner et al. } \\
1979\end{array}$ & 1 & $\begin{array}{l}\text { Congestive heart } \\
\text { failure }\end{array}$ & $\mathrm{N} / \mathrm{A}$ & $\begin{array}{l}\text { Endocardial fibrosis, intima, and inner } \\
\text { elastic membrane destruction of the } \\
\text { coronary arteries }\end{array}$ \\
\hline Carmel el al. 1980 & 1 & $\begin{array}{l}\text { Congestive heart } \\
\text { failure }\end{array}$ & Cardiomyopathy & N/A \\
\hline $\begin{array}{l}\text { Brandstetter et al. } \\
1990\end{array}$ & 1 & $\begin{array}{l}\text { Congestive heart } \\
\text { failure }\end{array}$ & Right ventricular dilated cardiomyopathy & N/A \\
\hline $\begin{array}{l}\text { Geraghty et al. } \\
1992\end{array}$ & 1 & $\begin{array}{l}\text { Congestive heart } \\
\text { failure }\end{array}$ & $\mathrm{N} / \mathrm{A}$ & $\begin{array}{l}\text { Patchy endocardial fibrosis, intimal } \\
\text { proliferation in the coronary arteries }\end{array}$ \\
\hline Chenel et al. 1993 & 1 & $\begin{array}{l}\text { Congestive heart } \\
\text { failure }\end{array}$ & $\begin{array}{l}\text { Cardiomegaly, hypertrophic ventricular } \\
\text { septum }\end{array}$ & N/A \\
\hline $\begin{array}{l}\text { Ogier de Baulny } \\
\text { et al. } 1998\end{array}$ & 3 & Cardiomyopathy & N/A & N/A \\
\hline Longo et al. 2005 & 2 & Cardiomyopathy & $\mathrm{N} / \mathrm{A}$ & N/A \\
\hline $\begin{array}{l}\text { Profitlich et al. } \\
2009\end{array}$ & 4 & $\begin{array}{l}\text { Asymptomatic } \\
\text { with low LV } \\
\text { shortening } \\
\text { fraction }\end{array}$ & $\begin{array}{l}\text { Left ventricular noncompaction }(n=3) \text {, } \\
\text { prominent left ventricular trabeculation } \\
(n=1)\end{array}$ & $\mathrm{N} / \mathrm{A}$ \\
\hline De Bie et al. 2009 & 1 & $\begin{array}{l}\text { Symmetrical } \\
\text { intrauterine } \\
\text { growth } \\
\text { retardation }\end{array}$ & $\begin{array}{l}\text { Thickened right ventricle, dilated } \\
\text { cardiomyopathy, and small } \\
\text { perimembranous ventricular septal } \\
\text { defect }\end{array}$ & N/A \\
\hline This report & 1 & Hydrops fetalis & Left ventricular noncompaction & N/A \\
\hline
\end{tabular}

Table 2 Enzymatic, biochemical, and molecular aspects of $c b l C$ patients with congestive heart failure and cardiomyopathy

\begin{tabular}{|c|c|c|c|c|c|c|}
\hline Reference & $\begin{array}{l}\text { Number of } \\
\text { patients }\end{array}$ & $\begin{array}{l}\text { Cellular } \\
\text { biochemistry/ } \\
\text { molecular genetics }\end{array}$ & $\begin{array}{l}\text { Plasma total } \\
\text { homocysteine } \\
(\mathrm{tHcy})(\mu \mathrm{mol} / \mathrm{L} ; \\
\text { normal }=3-9.8)\end{array}$ & $\begin{array}{l}\text { Homocysteine plasma } \\
(\mu \mathrm{mol} / \mathrm{L} ; \text { normal }=0)(\mathrm{P}) \text { or } \\
\text { urine }(\mathrm{U})(\mathrm{mmol} / \mathrm{mol} \mathrm{Cr} \text {; } \\
\text { normal }=0)\end{array}$ & $\begin{array}{l}\text { Plasma methionine } \\
(\mu \mathrm{mol} / \mathrm{L} ; \text { normal }= \\
8-51)\end{array}$ & $\begin{array}{l}\text { Urine MMA } \\
(\mathrm{mmol} / \mathrm{mol} \mathrm{Cr} \\
\text { normal }<10)\end{array}$ \\
\hline $\begin{array}{l}\text { Baumgartner et al. } \\
1979\end{array}$ & 1 & - & N/A & $\begin{array}{l}P=\text { present } \\
U=\text { high }\end{array}$ & Low & High \\
\hline Carmel et al. 1980 & 1 & + & N/A & $\begin{array}{l}\mathrm{P}=\text { present } \\
\mathrm{U}=151.7\end{array}$ & 7 & 4,751 \\
\hline $\begin{array}{l}\text { Brandstetter et al. } \\
1990\end{array}$ & 1 & + & N/A & $\begin{array}{l}\mathrm{P}=\text { present } \\
\mathrm{U}=3.1\end{array}$ & 3 & 1,705 \\
\hline Geraghty et al. 1992 & 1 & - & N/A & $\begin{array}{l}\mathrm{P}=37 \\
\mathrm{U}=\mathrm{N} / \mathrm{A}\end{array}$ & 0 & 1,187 \\
\hline Chenel et al. 1993 & 1 & + & N/A & $\begin{array}{l}\mathrm{P}=25 \\
\mathrm{U}=1,800\end{array}$ & 8 & 2,000 \\
\hline $\begin{array}{l}\text { Ogier de Baulny } \\
\text { et al. } 1998\end{array}$ & 3 & - & N/A & $\begin{array}{l}\mathrm{P}=\mathrm{N} / \mathrm{A} \\
\mathrm{U}=\mathrm{N} / \mathrm{A}\end{array}$ & N/A & N/A \\
\hline \multirow[t]{2}{*}{ Longo et al. 2005} & 2 & + & 71 & $\begin{array}{l}\mathrm{P}=\mathrm{N} / \mathrm{A} \\
\mathrm{U}=\mathrm{N} / \mathrm{A}\end{array}$ & N/A & 285 \\
\hline & & + & 52 & $\begin{array}{l}\mathrm{P}=\mathrm{N} / \mathrm{A} \\
\mathrm{U}=\mathrm{N} / \mathrm{A}\end{array}$ & N/A & 170 \\
\hline \multirow[t]{4}{*}{ Profitlich et al. 2009} & 4 & $271 \operatorname{dupA} / 271 \operatorname{dup} \mathrm{A}$ & 95 & $\begin{array}{l}\mathrm{P}=\mathrm{N} / \mathrm{A} \\
\mathrm{U}=\mathrm{N} / \mathrm{A}\end{array}$ & N/A & 266 \\
\hline & & 271dupA/271dupA & 107 & $\begin{array}{l}\mathrm{P}=\mathrm{N} / \mathrm{A} \\
\mathrm{U}=\mathrm{N} / \mathrm{A}\end{array}$ & N/A & 196 \\
\hline & & $\begin{array}{l}\text { 547_8delGT/ } \\
\text { 285dupA }\end{array}$ & 64 & $\begin{array}{l}\mathrm{P}=\mathrm{N} / \mathrm{A} \\
\mathrm{U}=\mathrm{N} / \mathrm{A}\end{array}$ & N/A & 31 \\
\hline & & $608 \mathrm{G}>\mathrm{A} / 608 \mathrm{G}>\mathrm{A}$ & 42 & $\begin{array}{l}\mathrm{P}=\mathrm{N} / \mathrm{A} \\
\mathrm{U}=\mathrm{N} / \mathrm{A}\end{array}$ & N/A & 20 \\
\hline De Bie et al. 2009 & 1 & 271dupA/271dupA & 236 or 45 & $\begin{array}{l}\mathrm{P}=66 \\
\mathrm{U}=\mathrm{N} / \mathrm{A}\end{array}$ & 5 & High \\
\hline This report & 1 & $271 \operatorname{dupA} / 271 \operatorname{dupA}$ & 55 & $\begin{array}{l}\mathrm{P}=2 \\
\mathrm{U}=\mathrm{N} / \mathrm{A}\end{array}$ & 42 & 250 \\
\hline
\end{tabular}


The presence of LVNC in utero with cardiac dysfunction in the propositus is consistent with a model in which the MMACHC gene product may play a role in cardiac development. In a recent study, Mmachc mRNA was present and highly expressed in the bulbus cordis and endocardial cushion at E11 in mice (Pupavac et al. 2011). The role of MMACHC in development is unknown but given that MMADHC, a related enzyme in the pathway and a MMACHC binding partner (Plesa et al. 2011), was not expressed in the same temporal/spatial pattern may indicate a unique role for MMACHC in cardiac physiology and/or development (Pupavac et al. 2011). Other factors related to the biology of MMACHC may be contributory: MMACHC can localize to mitochondria (Pagliarini et al. 2008) and $c b l \mathrm{C}$ patients and their fibroblasts have increased markers of oxidative stress suggesting underlying mitochondrial dysfunction (Richard et al. 2009; Mc Guire et al. 2009). In addition, patient-derived cells display global dysregulation of cytoskeletal proteins, such as actin, lamin $\mathrm{A} / \mathrm{C}$, and collagen VI (Hannibal et al. 2011). Therefore, it seems reasonable that MMACHC deficiency could result in developmental cardiac defects, possibly by inducing secondary cellular ultrastructural changes and/or mitochondrial dysfunction. This hypothesis is consistent with the observation that genes responsible for LVNC have functions associated with cytoskeletal and/or mitochondrial metabolism, a finding that perhaps could be investigated in experimental animal models of $c b l C$ disease.

To our knowledge, this is the first case of LVNC presenting prenatally in a patient with $c b l \mathrm{C}$ disease. The fact that a number of other $c b l \mathrm{C}$ patients have also been reported to have cardiomyopathy (Table 1) extends the hypothesis of a disease association between $c b l \mathrm{C}$ and cardiac pathology (McCully 1969; Profitlich et al. 2009) and highlights the importance of assessing all patients with $c b l C$ for cardiac disease. The findings in the patient reported here also emphasize that a metabolic evaluation for $c b l C$ should be considered in the setting of nonimmune hydrops fetalis, especially if fetal cardiomyopathy is present.

\section{Synopsis}

A case report of prenatal onset left ventricular noncompaction and hydrops in cobalamin $\mathrm{C}$ disease.

\section{References}

Andersson HC, Marble M, Shapira E (1999) Long term outcome in treated combined methylmalonic academia and homocystinemia. Genet Med 1(4):146-150

Baumgartner ER, Wick H, Maurer R et al (1979) Congenital defect in intracellular cobalamin metabolism resulting in homocysteinuria and methylmalonic aciduria I Case report and histopathology. Helv Paediatr Acta 34(5):465-482

Beken S, Cevik A, Turan O et al (2011) A neonatal case of left ventricular noncompaction associated with trisomy 18 . Genet Couns 22(2):161-164

Bleyl SB, Mumford BR, Thompson V et al (1997) Neonatal, lethal noncompaction of the left ventricular myocardium is allelic with Barth syndrome. Am J Hum Genet 61(4):868-872

Blinder JJ, Martinez HR, Craigen WJ et al (2011) Noncompaction of the left ventricular myocardium in a boy with a novel chromosome 8p23.1 deletion. Am J Med Genet A 155A(9): $2215-2220$

Brandstetter Y, Weinhouse E, Splaingard ML, Tang TT (1990) Cor pulmonale as a complication of methylmalonic acidemia and homocystinuria (Cbl-C type). Am J Med Genet 36(2):167-171

Carmel R, Bedros AA, Mace JW, Goodman SI (1980) Congenital methylmalonic aciduria-homocystinuria with megaloblastic anemia: Observations on response to hydroxocobalamin and on the effect of homocysteine and methionine on the deoxyuridine suppression test. Blood 55(4):570-579

Carrillo-Carrasco N, Sloan J, Manoli I et al (2011) A detailed phenotype and long-term outcome of early onset cblC disease. Mol Genet Metab 102(3):246-247

Chang B, Nishizawa T et al (2011) Identification of a novel TPM1 mutation in a family with left ventricular noncompaction and sudden death. Mol Genet Metab 102(2):200-206

Chenel C, Wood C, Gourrier E et al (1993) Neonatal hemolyticuremic syndrome, methylmalonic aciduria and homocystinuria caused by intracellular vitamin B 12 deficiency Value of etiological diagnosis. Arch Fr Pediatr 50(9):749-754

Chin TK, Perloff JK, Williams RG et al (1990) Isolated noncompaction of left ventricular myocardium A study of eight cases. Circulation 82(2):507-513

De Bie I, Nizard SD, Mitchell GA (2009) Fetal dilated cardiomyopathy: an unsuspected presentation of methylmalonic aciduria and hyperhomocystinuria, Cbl-C type. Prenat Diagn 29(3): 266-270

Finsterer J, Stollberger C, Michaela J (2002) Familial left ventricular hypertrabeculation in two blind brothers. Cardiovasc Pathol 11(3):146-148

Finsterer J, Stöllberger C, Schubert B (2004) Acquired left ventricular hypertrabeculation/Noncompaction in mitochondriopathy. Cardiology 10 (4) 2:228-230

Finsterer J, Stöllberger C, Blazek G (2006) Neuromuscular implications in left ventricular hypertrabeculation/noncompaction. Int $\mathrm{J}$ Cardiol 110(3):288-300

Geraghty MT, Perlman EJ, Martin LS et al (1992) Cobalamin C defect associated with hemolytic-uremic syndrome. J Pediatr 120(6): 934-937

Hannibal L, DiBello PM, Yu M et al (2011) The MMACHC proteome: hallmarks of functional cobalamin deficiency in humans. Mol Genet Metab 103(3):226-239

Ichida F (2009) Left ventricular noncompaction. Circ J 73(1):19-26

Kanemoto N, Horigome H, Nakayama $J$ et al (2006) Interstitial 1q43-q43 deletion with left ventricular noncompaction myocardium. Eur J Med Genet 49(3):247-253

Lerner-Ellis JP, Tirone JC, Pawelek PD et al (2006) Identification of the gene responsible for methylmalonic aciduria and homocystinuria, Cbl-C type. Nat Genet 38(1):93-100

Longo D, Fariello G, Dionisi-Vici C et al (2005) MRI and 1H-MRS findings in early-onset cobalamin C/D defect. Neuropediatrics 36(6):366-372

Madan S, Madan-Khetarpal S, Park SC et al (2010) Left ventricular non-compaction on MRI in a patient with $22 \mathrm{q} 11.2$ distal deletion. Am J Med Genet A 152A(5):1295-1299 
Martinelli D, Deodato F, Dionisi-Vici C (2010) Cobalamin C defect: natural history, pathophysiology, and treatment. J Inherit Metab Dis 34(1):127-135, Epub 2010 Jul 15

Martinez HR, Belmont JW, Craigen WJ, Taylor MD, Jefferies JL (2011) Left ventricular noncompaction in Sotos syndrome. Am J Med Genet A 155A(5):1115-1118

Mc Guire PJ, Parikh A, Diaz GA (2009) Profiling of oxidative stress in patients with inborn errors of metabolism. Mol Genet Metab 98(1-2):173-180

McCully KS (1969) Vascular pathology of homocysteinemia:implications for the pathogenesis of arteriosclerosis. Am J Pathol 56(1): $111-128$

McMahon CJ, Chang AC, Pignatelli RH et al (2005) Left ventricular noncompaction cardiomyopathy in association with trisomy 13 . Pediatr Cardiol 26(4):477-479

Ogier de Baulny H, Gérard M, Saudubray JM, Zittoun J (1998) Remethylation defects: guidelines for clinical diagnosis and treatment. Eur J Pediatr 157(Suppl 2):S77-S83

Pagliarini DJ, Calvo SR, Chang B et al (2008) A mitochondrial protein compendium elucidates complex I disease biology. Cell 134(1):112-123

Pauli RM, Scheib-Wixted S, Cripe L et al (1999) Ventricular noncompaction and distal chromosome $5 \mathrm{q}$ deletion. Am J Med Genet 85(4):419-423

Plesa M, Kim J, Paquette SG et al (2011) Interaction between MMACHC and MMADHC, two human proteins participating in intracellular vitamin B12 metabolism. Mol Genet Metab 102(2):139-148

Profitlich LE, Kirmse B, Wasserstein MP et al (2009) High prevalence of structural heart disease in children with Cbl-C-type methylmalonic aciduria and homocystinuria. Mol Genet Metab 98(4):344-348

Pupavac M, Garcia MA, Rosenblatt DS, Jerome-Majewska LA (2011) Expression of Mmachc and Mmadhc during mouse organogenesis. Mol Genet Metab 103(4):401-405

Richard E, Jorge-Finnigan A, Garcia-Villoria J et al (2009) Genetic and cellular studies of oxidative stress in methylmalonic aciduria
(MMA) cobalamin deficiency type c (cblC) with homocystinuria (MMACHC). Hum Mutat 30(11):1158-1566

Richards A, Mao CY, Dobson NR (2009) Left ventricular non compaction: A rare cause of hydrops fetalis. Pediatr Cardiol 30(7):985-988, Epub 2009 Jun 9

Rosenblatt DS, Aspler AL, Shevell MI, Pletcher BA, Fenton WA, Seashore MR (1997) Clinical heterogeneity and prognosis in combined methylmalonic aciduria and homocystinuria (cblC). J Inherit Metab Dis 20(4):528-538

Sasse-Klaassen S, Probst S, Gerull B et al (2004) Novel gene locus for autosomal dominant left ventricular noncompaction maps to chromosome 11p15. Circulation 109(22):2720-2723, Epub 2004 Jun 1

Sellars EA, Zimmerman SL, Smolarek T et al (2011) Ventricular noncompaction and absent thumbs in a newborn with tetrasomy 5q35.2-5q3.5: An association with Hunter-McAlpine syndrome? Am J Med Genet A 155A(6):1409-1413

Stöllberger C, Finsterer J, Valentin A et al (1999) Isolated left ventricular abnormal trabeculation in adults is associated with neuromuscular disorders. Clin Cardiol 22(2):119-123

Stöllberger C, Finsterer J, Voigtlander T, Slany J (2003) Is left ventricular hypertrabeculation/noncompaction a cardiac manifestation of Fabry's disease? Z Kardiol 92(11):966-999

Tang S, Batra A, Zhang Y et al (2010) Left ventricular noncompaction is associated with mutations in the mitochondrial genome. Mitochondrion 10(4):350-357

Thienpont B, Mertens L, Buyse G et al (2007) Left-ventricular noncompaction in a patient with monosomy 1p36. Eur J Med Genet 50(3):233-236

Wang JC, Dang L, Mondal TK, Khan A (2007) Prenatally diagnosed mosaic trisomy 22 in a fetus with left ventricular non-compaction cardiomyopathy. Am J Med Genet A143A(22):2744-2746

Xing Y, Ichida F, Matsuoka T et al (2006) Genetic analysis in patients with left ventricular noncompaction and evidence for genetic heterogeneity. Mol Genet Metab 88(1):71-77 